\title{
Verbal Interactions in EFL at the Senior Vocational High School
}

\author{
Ristyananda, I.P1*, Tantra, D.K², Mahendrayana, $\mathbf{G}^{3}$
}

${ }^{123}$ English Education Department Ganesha University of Education

\begin{tabular}{l}
\hline A R T I C L E I N F O \\
\hline Received 25 February \\
2020 \\
Received in revised \\
Form 29 March 2020 \\
Accepted 20 April 2020 \\
Available online 29 May \\
2020 \\
\hline
\end{tabular}

\section{Keywords:}

speech acts,

locutionary

acts,

illocutionary

acts,

perlocutionary

acts

\begin{abstract}
A B S T R A C T
This study was focused on identifying, classifying and understanding speech acts produced by teachers and tenth-grade students of Senior Vocational High School. The study was focused on locutionary acts, illocutionary acts, and perlocutionary produced during the EFL learning process under the theory of Austin (1962) and the theory of Searle (1969). Descriptive Qualitative design was employed in this study. Two teachers and sixty students of SMK Negeri 3 Singaraja were chosen as the sample in this study. The data were gathered through observation assisted by video recorder. The data were analyzed descriptive-qualitatively. The result of the study showed that the teachers produced all types of speech acts, namely directive, commisive, expressive, declarative and assertive. The most dominant type produced was directive act in form of requesting. It was used to ask the students for doing something and giving instruction. The other types of speech acts were not dominant. Meanwhile, the students produced three types of speech acts, namely directive, expressive, and assertive. The most dominant type produced was directive act in form of requesting through asking question and telling, through telling their daily routine. Meanwhile Expressive act in form of welcoming through greeting the teacher and assertive in form of describing through describe their friends, parents, and teachers. In additions, it was shown that the teachers produced more speech acts than the students, and the entire locutionary acts produced were understood by the interlocutors, it can be seen from appropriate respond performed.
\end{abstract}

\section{Introduction}

Communication is conveying information and knowledge from one person to another. This statement in line with (Keyton 2011) communication is conveying information and knowledge from one person to another. It can be concluded that communication is express and transfer an idea, feeling, knowledge or information which was done by more than one person. When communicating with each other, people mostly communicate using words or utterances to express their idea or feeling. Communicate through words or utterances are known as verbal communication. Beside communicate verbally; the people may use their gesture or body language such as moving their hands, nodding, and using a facial expression in order to communicate or emphasizing the verbal communication. Communicate by using body language or gesture is known as non-verbal communication. In social interaction, the speaker and addressee must understand each other. It means that the addressee must give an appropriate response to what the speakers mean. This statement in line with Brown (2001 p-165), who stated that interaction occurs when the people who involved in that interaction understand each other. It can be concluded that if the speakers and addressee understand to each other, the addressees know what the speakers mean and able to give appropriate responses, and then the interactions between the speakers and the addressees happened.

In every interaction, the speakers not only express information or feeling but also convey an action in their utterances such as, greeting, welcoming, explaining, requesting, etc. which is known as speech act. According to Searle (1969 p-16), speech act is the smallest unit of linguistic communication which is produced by people and act on those utterances. Speech act cannot be separated from every utterance in verbal interaction, because when expressing something the people not only produce utterances which contained of grammatical and words but they perform an action through those utterances. It makes speech can be occurred in every interaction. For example are in society, in film, in books, and as the focused on this research is in the educational field in educational field, 
Since English as a foreign language in Indonesia, a speech act may occur when the interaction between teacher and students in the learning process at EFL classroom. In the learning process, the teachers not only transfer the knowledge but in their utterances also convey an action, for example, commanding, requesting, ordering, asking, etc. to the students. Related to the latest curriculum which is implemented in Indonesia which is known as curriculum 2013, the students should be more active than the teacher and has a purpose to make the students able to communicate personally, interpersonally, and transactional. To make communicative interaction, the students must be able to understand what are the speakers said, what the speaker meant, and give appropriate responses to them.

However, the students may confuse in interpreting the utterances spoken by the teacher. Since the teachers mean something by not exactly what are they said. For example, when the teacher said "The room is very hot" it may have other meaning besides the literal meaning. According to Austin (1962) theory, 1) the literal meaning of the utterance is known as locutionary act, 2) in others meaning, it may mean the teacher asking the students to open the window because the room is very hot which is known as illocutionary act, and 3) the respond of the students is known as perlocutionary act. If the students respond to the teacher by turning on the air conditioner it can be said that the students understand what are the speakers meant or the illocutionary of teachers' utterance. meanwhile, if the students respond to the teacher by saying" yes the room is very hot" without doing any action, it means that the students do not understand about what are teachers mean. It can be concluded that the use of appropriate speech act is to determine how the interaction in the classroom will happen.

The difficulties in interpreting what are the teachers conveyed in their utterances while in the learning process happened at SMK Negeri 3 Singaraja. Some of the students did not really understand what the teacher actually said. Based on the preliminary observation when the teachers utter "students can you hear me" it can be interpreted in term of locutionary and illocutionary act. In term of locutionary act, the teacher is asking the students whether they listen to the teacher explanation or not, meanwhile in term of illocutionary act, it can be as a command to make students keeping silent and listening to teachers' explanation indirectly. If the students understand what the teacher meant, they will respond to the teacher by keeping silent and listening to the teacher explanation. In fact, the students respond to the teacher by saying "yes" but the students still talked with their friends. It means the students failed to interpret the illocution act of the teachers' utterance or the teacher failed to choose the variation of form and function of speech act.

Based on the literature above, it was interested to identifying, classifying, and understanding the types of speech act produced in verbal interaction during learning process at SMK Negeri 3 Singaraja, academic years 2018/2019.

\section{Methods}

This present study applied descriptive qualitative design, where data collection procedure was done with one instrument, namely an observation checklist on EFL verbal interaction. The obtained data were analyzed using a descriptive qualitative analysis. Descriptive qualitative analysis was a method which is used to determine the knowledge of the subject of the research in certain thing (Lanbert 2012). Descriptive qualitative gathered words instead numbers. It means this study was focused to describe the data instead counted the data used a large of number.

The population of this research was all of the students in SMK Negeri 3 Singaraja, which is in total 2400 students. Because the target population was too large, the sample recruited only two intact classes. The total of sample recruited was 60 students and two teachers who taught in X TKRO 3 and X TPM 2. Tenth grade students were chosen because they learn English at first time in senior vocational high school and there were a transition between junior high school to senior vocational high school. Purposive sampling used in order to get the representative of the data.

Observation the learning processes assisted by video recorder was conducted in order to collect the data. The instrument used was observation checklist consisted of anecdotal records. The records consisted of speech acts produced during the EFL verbal interaction in two lesson plans and two classroom meeting. record noted the speech acts, situations of classroom, learning stages, activity, the structures of the speech, verbs synonym and examples

\section{Result And Discussion}

In the first learning situations observed were meant to understand a poem in terms of its social function, text structure, and language element. The EFL learning was focused on writing a short poem paragraph in English. Meanwhile the second learning situation was meant to understand a daily routine in 
terms of its social function, text structure, and language element. The EFL learning was focused on writing a short daily routine paragraph in English. To achieve the pre-determined learning goal, the EFL learning activities were divided into three stages, namely pre-activity, whilst activity, and post-activity. The preactivity was meant for an introductory stage in order to prepare the students' readiness for up-coming lesson. There were found two pre-learning activities: greeting and checking students' attendance. There were twelve speech of two learning situation found in greeting, for example:

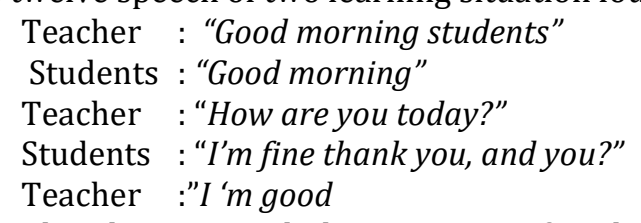

The above record shows a unit of verbal interaction between the interlocutors. When analyzed descriptively in terms of speech acts, there are six speech acts which could be classified accordingly. The locutionary acts produced could be classified as expressive acts and directives act. In the expressive act especially of the welcoming types, the examples is "Good morning", meanwhile in directive act, the example are "how are you today" "I'm fine thank you, and you?".

In term of illocutionary acts in the above example, the students understood the teachers' greeting "Good morning students" by give proper respond greeted the teacher back "Good morning students". Another example, the students understand the teachers' asking "Good morning students" by giving appropriate respond "I'm fine thank you and ask back to the teacher by "And, you?". The teacher understands as well about the students' asking and responds by saying "I ' $m$ good".

In term of perlocutionary acts, the students respond to the teachers' greeting "Good morning students" by greeted the teacher back "Good morning students". Another example, the students respond to the teachers' asking "How are you today?" by giving appropriate respond "I'm fine thank you and ask back to the teacher by "And, you...?" The teacher responds by saying "I 'm good".

In checking students attendance, there were twelve speech found. The example analyzed in term of locutionary acts, illocutionary acts, and perlocutionary acts, described bellow:

Teacher : "Any one absent?"

Students : One pak

Teacher : Who is absent?

Students : Dharma Puspita

The above example shows that there are four speech acts which could be classified accordingly. The locutionary acts produced could be classified as directives act which found in teachers' locutionary act. The examples are: "Any one absent?" Who is absent?

In term of illocutionary acts from the example of the data transcription above, the students understand teachers' locutionary "Any one absent?" By give appropriate respond "One pak". Another example is, the teacher ask "Who is absent?" and the students understood by saying "Dharma Puspita "

In terms of perlocutionary from the example of the data transcription above, the students respond to the teachers' speech act in form of asking "Any one absent?" the students respond verbally by saying "One pak". Another example is, the teacher ask "Who is absent?" and the students respond verbally by saying "Dharma Puspita

Whilst activity as the main activity of the learning process. There were four activities found, they were questioning, exploring, associating, and communicating. The examples are described below:

In questioning, the speech analyze descriptively in terms of locutionary acts, illocutionary acts, perlocutionary acts for example:

Teacher : "do you know what is poem?"

Students : "puisi" (poem)

Teacher :"yes poem is puisi"

The locutionary acts or what the interlocutors produced could be classified as directives act especially in requesting and telling types. The example of requesting is "do you know what is poem?" meanwhile the example of telling is" yes poem is puisi"

In terms of illocutionary acts, the students understand the teachers' locutionary "do you know what is poem?" the students respond by saying "puisi" (poem)

In terms of perlocutionary acts, the students able to give proper respond to the teachers' locutionary verbally by saying "puisi" (poem).

In exploring activities the example of the data analysis is described below:

Teacher : "Look at the pattern of this sentence"

Students : : (students respond by paying attention to the sentence) 
Teacher

Students

Teacher

Teacher

Students

Teacher

Students

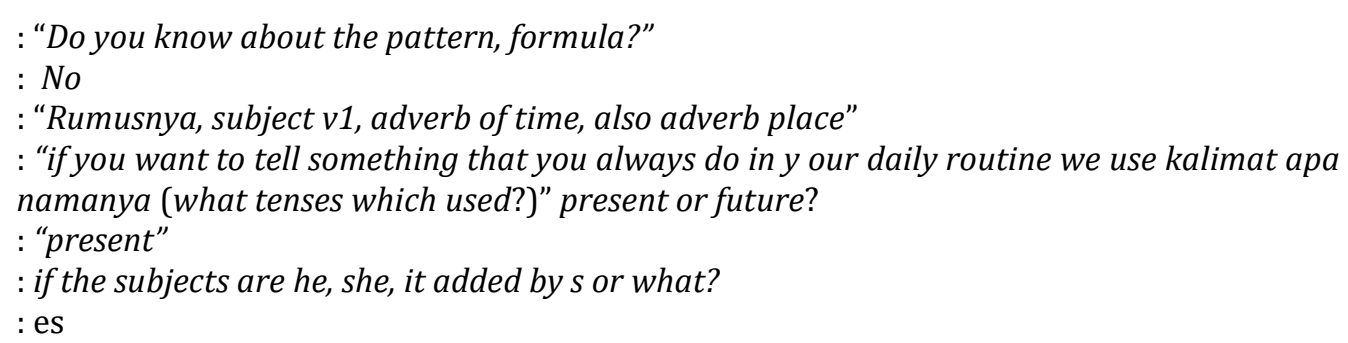

The locutionary acts produced could be classified as directives act especially in ordering and requesting types which found in teachers' locutionary act. The example ordering is: "Look at the pattern of this sentence". Meanwhile in requesting are "Do you know about the pattern, formula?" "Present or future?" "If the subjects are he, she, it added by s or what?

In terms of illocutionary acts the students understood by the teachers' order "Look at the pattern of this sentence" the students respond it non-verbally by paying attention to the teachers' sentence. Another example was teachers' request in order to ask the student "Do you know about the pattern, formula?" the students respond verbally by saying " $N o$ ", because they did not know the pattern of the sentence.

In terms of perlocutionary acts the students respond the teachers' order "Look at the pattern of this sentence" non-verbally by performing act of paying attention to the teachers' sentence. Another example in teachers' request in order to ask the student "Do you know about the pattern, formula?" the students respond verbally by saying "No", because they did not know the pattern of the sentence.

In associating activities the example of the data analysis is described below:

Teacher : Please write the exercise in your book, not in the copy

Students : yes

In term of locutionary acts, the speech can be classified into directive act of request "Please write the exercise in your book, not in the copy"

In term of illocutionary acts the students understood to the teachers request by saying "yes"

In perlocutionary acts, the students able to give proper action to the teachers' request by saying "yes". The students respond the teachers' request verbally.

In communicating the interlocutors produced several speech which can be analyzed descriptively in terms of speech acts. For example :

Teacher : "Ya kamu apriana kedepan baca pekerjaan kamu?

Students : "My daily activity, I wake up at six in the morning, and then I take a bath, after that I go to school. After that I go home. After that I sleep"

Teacher : "Thankyou apriana"

In terms of locutionary act, the speech above can be classified into order acts "Ya kamu apriana kedepan baca pekerjaan kamu?, into thanking acts "Thank you apriana"

In terms of illocutionary acts, the students understood the techers' order by performing an act of reading his work to the in fron of the class

In terms of perlocutionary acts, the student respond it by perform an act of reading his work to the in front of the class.

In post activity the speech produced by the interlocutors described below:

: "My daily activity, I wake up at six in the morning, and then I take a bath, after that I go to school. After that I go home. After that I sl apriana"

Teacher : "Well the others students who are not read their work, Please just submit your work"

Students : (the students respond by collect their works)

Teacher :"Well students because time is up, see you next meeting"

Students : "see you"

The locutionary could be classified as directive and commisive act found in teachers' locutionary act. In directive act especially in requesting the examples is "Please just submit your work". Meanwhile the commissive act especially in promising the example is "Well students because time is up, see you next meeting"

In terms of illocutionary acts, the students understood the teachers' request "Well the others students who are not read their work, Please just submit your work" the students respond it non-verbally by performing the act of collecting their work and submit it to the teacher

In terms of perlocutionary acts,the students respond the teachers' request "Well the others students who are not read their work, Please just submit your work" the students respond it non-verbally by performing the act of collecting their work and submit it to the teacher. 
Based on the data analysis there were 283 speech produced by the interlocutors in two meeting or learning situation. In both learning situation there were 144 locutionary acts and 139 perlocutionary acts were produced by the interlocutors. Locutionary act is an act of saying something (Austin 1962). Based on the data analysis, locutionary act mostly produced by the teacher than than the students.

\section{Locutionary acts}

Locutionary act produced in every activity in learning stages for example in pre-activity, the interlocutors say "Good morning" or good afternoon, meanwhile in checking students' attendance the teacher usually said "is there any one absent today" or asking directly who were not attend the class for example "where is arya". In whilst-activity, defined into five activities they are observing, questioning, exploring, associating and communicating. Based the data analysis the teachers did not following all of those five learning stages but only some of them. For example the locutionary act which is used in questioning like "do you know what is daily routine". The example teachers' locutionary act in exploring is "the pattern of simple present tense is s+ v1 + adverb of place". In associating mostly the locutionary act were used like "please write one of your daily routine".

\section{Illocutionary acts}

In terms of illocutionary acts, most of the teachers' locutionary were understood by the students. Illocutionary is produced in order to make the hearer doing something (Searle 1969). It can be shown the proper respond given regarding to the locutionary. Most of the students able to give appropriate respond to the teacher locutionary, whether sometime the teacher should switch the language students' first or second language. It can make the student able to give appropriate respond to teachers' locutionary.

\section{Perlocutionary acts}

In perlocutionary act, it is about the respond given by the interlocutors. A Perlocutionary act is a speech produced in order to affecting the hearer to do something (Austin 1962). Related to the data analysis the perlocutionary produced by interlocutors were in form of verbally and non-verbally. In verbally for example when the teacher said "how are you today" the students respond it by saying "I am fine thak you". Meanwhile in nonverbal respond, for examples in teachers' request "please open your book pages 1 " then the students respond it without say anything but perform an act of open the book.

Concerning to the types of speech act which is developed by Searle (1969) namely; assertive, directive, commissive, expressive, and declarative. in two learning situation the mostly used is directive in sub types of requesting.

\section{Conclussion}

There were 144 locutionary acts in total produced during the EFL learning process both in the first learning situation and the second learning situation. locutionary acts mostly produced by the teachers. The teachers produced all types of speech acts, namely directive, commisive, expressive, declarative and assertive. The most dominant type produced was directive act in form of requesting. It was used to ask the students for doing something and giving instruction. The other types of speech acts were not dominant. Meanwhile, the students produced three types of speech acts, namely directive, expressive, and assertive. The most dominant type produced was directive act in form of requesting through asking question and telling, through telling their daily routine, it is because the topic is about daily routine. Meanwhile Expressive act in form of welcoming it is used to greet the teacher and assertive in form of describing it is used to describe their friends, parents, and teachers because the materials is about describing friends, parents, and teachers in form of poem. In additions, it was shown that, the teachers produced more speech acts than the students, and the entire locutionary acts produced were understood by the interlocutors, it can be seen from appropriate respond performed.

\section{Reference}

Azhari, a. s. (2018). Speech Acts of Classroom Interaction. International Journal of Linguistics, Literature and Culture, 24-45.

Austin, J. L. (1962). How To Do Things With Words. London:Oxford University Press. 
Barnas, A. (2015). Analyzing Speech Act Found In The EFL Class. ELT Perspective.

Brown H.D. (2000) TEACHING by PRINCIPLES A Interactive Approach to Language Pedagogy Second Edition. Pearson Education

Bogdan, R. C., \& Biklen, S. K. 1982. Qualitative Research for Education: An Introduction to Theory and Methods. Boston: Allyn and Bacon.

CJ, J. (2018). Speech Acts in EFL Classroom at Islamic Senior High. Journal of Language and Literature .

Creswell, J. W. (2014). Research design : qualitative, quantitative, and mixed methods approaches 4th edition. SAGE PUBLICATION.

Azhari, a. s. (2018). Speech Acts of Classroom Interaction. International Journal of Linguistics, Literature and Culture , 24-45.

Austin, J. L. (1962). How To Do Things With Words. London:Oxford University Press.

Barnas, A. (2015). Analyzing Speech Act Found In The EFL Class. ELT Perspective .

Brown H.D. (2000) TEACHING by PRINCIPLES A Interactive Approach to Language Pedagogy Second Edition. Pearson Education.

Bogdan, R. C., \& Biklen, S. K. 1982. Qualitative Research for Education: An Introduction to Theory and Methods. Boston: Allyn and Bacon.

CJ, J. (2018). Speech Acts in EFL Classroom at Islamic Senior High. Journal of Language and Literature .

Creswell, J. W. (2014). Research design : qualitative, quantitative, and mixed methods approaches 4th edition. SAGE PUBLICATION.

Kementerian Pendidikan Dan Kebudayaan. (2014). Konsep dan Implementasi Kurikulum 2013. Paparan Wakil Menteri Pendidikan dan Kebudayaan R.I Bidang Pendidikan. Jakarta

Keyton, J. (2011). Communication and organizational culture: A key to understanding. Thousand Oaks, CA: Sage.

Searle, J. R., \& vandervaked, D. (1985). founddation of illocutionary logic. CAMBRIDGE UNIVERSITY PRESS.

Searle, J. R. (1979). Expression and Meaning: Studies in the Theory of Speech Acts.Oxford University Press.

Searle, J. R. (1999). Mind, Language and Society: Philosophy in the Real World. Phoenix: Guernsey Press Co.

Searle,J.R. (1969). Speech Acts. Cambridge : Cambridge University Press

Seken, K. 2015, introduction to pragmatics :A Course Book For Beginners. Graha Ilmu Press

Thoyyibah, S. M. (2017). A Speech Act Analysis of Teacher Talk in an EFL Classroom. International Journal of Education , 73-81.

Yule, G. (1996). Pragmatics. Oxford University Press.

Zayed, D. N. (2014). Jordanian EFL Teachers' and Students' Practice of Speech. International Journal on Studies in English Language and Literature (IJSELL) , 1-10.

Zulianti, H. (2018). Speech Acts on EFL Learners' Teaching Performance. Jurnal SMART , 93-106 